Article

\title{
Pretreatment Affects Activated Carbon from Piassava
}

\author{
Jonnys Paz Castro $1,2,3, * \mathbb{C}$, João Rodrigo C. Nobre ${ }^{3}{ }^{\circledR}$, Alfredo Napoli ${ }^{4}$, \\ Paulo Fernando Trugilho ${ }^{1}$ (D) Gustavo H. D. Tonoli ${ }^{1}\left(\mathbb{D}\right.$, Delilah F. Wood ${ }^{5, *(D)}$ and \\ Maria Lucia Bianchi ${ }^{6, * \text { (D) }}$ \\ 1 Department of Forest Science (DCF), Federal University of Lavras, C.P. 3037, Lavras 37200-000, Brazil; \\ trugilho@dcf.ufla.br (P.F.T.); gustavotonoli@yahoo.com.br (G.H.D.T.) \\ 2 Department of Forest Products (DPF), Forest Institute (IF), Federal Rural University of Rio de Janeiro, \\ Rodovia BR 465, Km 07, C.P. 74527, 23890-000 Seropédica, Brazil \\ 3 Center for Natural Sciences and Technology (CCNT), State University of Pará, Rodovia PA-125, s/n, \\ Paragominas 68625-000, Brazil; rodrigonobre@uepa.br \\ 4 Biomass, Wood, Energy, Bioproducts Research Unit, CIRAD, 73 Rue Jean François Breton, \\ 34398 CEDEX5 Montpellier, France; alfredo.napoli@cirad.fr \\ 5 Bioproducts Research, USDA ARS WRRC, Albany, CA 94710, USA \\ 6 Department of Chemistry (DQI), Federal University of Lavras, C.P. 3037, Lavras 37200-000, Brazil \\ * Correspondence: jonnys_33@hotmail.com (J.P.C.); de.wood@usda.gov (D.F.W.); bianchi@ufla.br (M.L.B.); \\ Tel.: +1-510-559-5653 (D.F.W.)
}

Received: 28 May 2020; Accepted: 29 June 2020; Published: 2 July 2020

\begin{abstract}
The specificity of activated carbon (AC) can be targeted by pretreatment of the precursors and/or activation conditions. Piassava (Leopoldinia piassaba and Attalea funifera Martius) are fibrous palms used to make brushes, and other products. Consolidated harvest and production residues provide economic feasibility for producing AC, a value-added product from forest and industrial residues. Corona electrical discharge and extraction pretreatments prior to $\mathrm{AC}$ activation were investigated to determine benefits from residue pretreatment. The resulting AC samples were characterized using elemental analyses and FTIR and tested for efficacy using methylene blue and phenol. All resulting AC had good adsorbent properties. Extraction as a pretreatment improved functionality in AC properties over Corona electrical discharge pretreatment. Due to higher lignin content, AC from L. piassaba had better properties than that from A. funifera.
\end{abstract}

Keywords: piassava; Bahia; Amazon; Attalea funifera; Leopoldinia piassaba; corona discharge; electrical discharge; agricultural residues

\section{Introduction}

Activated carbons (ACs) are widely used in many environmental remediation processes because of their high adsorption capacity. ACs can remove a wide variety of pollutants in aqueous environments by having large surface presence of functional groups with affinities for various adsorbates [1]. The use of ACs in effluent purification improved the taste, smell, color, UV absorbance and oxidability of treated water [2]. Various raw materials, including wood, bone, coconut shells, coconut endocarp, sugarcane bagasse and fruit seeds [3,4] have been used to produce ACs with different characteristics. The choice of precursors and activation conditions make it possible to design ACs for specific applications [5]. All carbonaceous feedstock has the potential to be used for AC manufacture but not all are economically feasible mostly because of the expense of gathering and transporting the feedstock if left in the field. If the feedstock is already consolidated into a relatively small area, such as a lumber mill or processing plant, the feedstock may be readily gathered, transported and treated. Better still would be to have localized plants set up to do the treatment. 
Piassava fibers have great economic importance in Brazil, mainly in the states of Bahia and Amazonas, where large-scale production generates large quantities of residues. The residues are typically discarded or burned in boilers for energy generation [6].

AC production from solid residues using thermal conversion could divert a portion of the otherwise problematic byproduct away from the waste stream [7]. The AC industry has used, in the last decades, some agricultural and industrial residues as precursors with the objective of valorizing these raw materials or coproducts [5].

Piassava fiber has a smooth and impermeable texture due to its chemical composition, which can influence the properties of the ACs. Thus, the study of the possible effects of fiber pretreatment may indicate the best way to produce ACs with specific physicochemical characteristics. Avelar et al. [1], who worked on Bahia piassava fibers (Attalea funifera Martius) without pretreatment, stated that piassava fibers are a good precursor for AC production. Castro et al. [6] surveyed the effect of pretreatments including mercerization, corona discharge and extraction on long, unmilled Amazon piassava fibers and verified that pretreatments affect the properties of the resulting ACs. The aim of this work was to validate the novel pretreatments by including a second species of piassava and limiting the study to two pretreatments including Corona electrical discharge and solvent extraction on milled and screened piassava residues (Leopoldinia piassaba and A. funifera) on the resulting AC properties to provide validation of the previous work [6] and to do a more comprehensive evaluation of the resulting ACs.

\section{Materials and Methods}

\subsection{Materials}

Members of two genera of palm fiber, Amazon piassava (L. piassaba) (AP) and Bahia piassava (A. funifera) (BP), were used in this study. AP fibers were residual biomass from forest harvests in São Gabriel da Cachoeira (Brazil). BP fiber residues were donated by the broom industry in João Monlevade (Brazil). AP and BP fibers were milled and screened to 60-mesh for most purposes and 270 mesh for elemental and infrared analyses as per requirements of the experimental protocol.

\subsection{Pretreatment of the Piassava Fibers}

Prior to carbonizing the samples, milled piassava fibers were untreated (AP-Un, BP-Un), subjected to Corona electrical discharge (AP-Co, BP-Co) or solvent extraction (AP-Ex, BP-Ex) pretreatments.

\subsection{Electrical Discharge Pretreatment}

AP and BP milled fibers were subjected to the electrical discharge produced by a Model PT-1 Corona Plasma Tech instrument (Corona, Brazil). A voltage of $10 \mathrm{kV}$ was applied to the fibers for $10 \mathrm{~min}$ at a distance of $2 \mathrm{~cm}$ between the sample and the discharge head. Corona pretreated samples were termed AP-Co and BP-Co.

\subsection{Extraction Pretreatment}

Milled AP and BP fibers were wrapped in filter paper (seed germination filter paper, $60 \mathrm{~g} \mathrm{~m}^{-2}$ ) to prevent loss of material and treated with a 2:1 toluene:ethanol solution for $8 \mathrm{~h}$ using Soxhlet extraction. The toluene:ethanol solution was removed and replaced with ethanol and extracted for an additional $6 \mathrm{~h}$. The samples were washed continuously with hot distilled water for $3 \mathrm{~h}$ and oven dried at $103 \pm 2{ }^{\circ} \mathrm{C}$ for $24 \mathrm{~h} \mathrm{[8]} \mathrm{resulting} \mathrm{in} \mathrm{extracted} \mathrm{AP-Ex} \mathrm{and} \mathrm{BP-Ex.}$

\subsection{Chemical Analysis of Untreated Precursor Material}

Chemical analyses of the fibers of AP-Un and PB-Un were determined according to the standard methods: Holocellulose [9], cellulose [10], insoluble lignin [11], acid-soluble lignin [12] and ash [13]. Hemicellulose content was determined by the difference between holocellulose and cellulose contents. 


\subsection{Activated Carbon (AC) Preparation}

ACs were produced from using 60-mesh untreated and pretreated piassava fibers. All materials were treated in a Fornitec F3-DM/T muffle furnace (Labnano, Rio de Janeiro, Brazil) at a heating rate of $100{ }^{\circ} \mathrm{C} \mathrm{h}^{-1}$ to $550^{\circ} \mathrm{C}$ and maintained for $1 \mathrm{~h}$, resulting in charcoal (AP-Ch, BP-CH). AP-Ch and BP-Ch were moved to a cylindrical chamber in a tubular furnace (Sanchis Industrial Furnaces, Model 2023, Porto Alegre, Brazil), and activated at $800^{\circ} \mathrm{C}$ (heating rate of $10^{\circ} \mathrm{C} \mathrm{min}^{-1}$ ) for $2 \mathrm{~h}$ in carbon dioxide environment at a flow rate of $150 \mathrm{~mL} \mathrm{~min}^{-1}$ resulting in 12 AC-treated samples: AP-Un-AC, BP-Un-AC, AP-Co-AC, BP-Co-AC, AP-Ex-AC and BP-Ex-AC.

\subsection{Elemental Analysis}

Elements (CHNS) of AP and BP samples from all steps were determined in an elemental analyzer (Vario MacroCube, Elementar Americas, Inc., Ronkonkoma, NY, USA), following the protocol described by Paula et al. [14]. Samples milled to 270 mesh, as specified in the protocol, were analyzed. Oxygen content was calculated by difference according to Equation (1).

$$
\mathrm{O}(\%)=100-\mathrm{C}(\%)-\mathrm{H}(\%)-\mathrm{N}(\%)-\mathrm{S}(\%)-\operatorname{ash}(\%)
$$

where $\mathrm{O}$ is oxygen, $\mathrm{C}$ is carbon, $\mathrm{H}$ is hydrogen, $\mathrm{N}$ is nitrogen and $\mathrm{S}$ is sulfur [13].

\subsection{Infrared Spectroscopy (FTIR)}

Specific functional groups of the 12 samples of $\mathrm{Ch}$ and ACs made from 270 mesh AP and BP were identified using Fourier transform infrared (FTIR) spectroscopy analysis (Digilab Excalibur FTS 3000, Bio-Rad, Hercules, CA, USA) in the spectral range of 400 to $4000 \mathrm{~cm}^{-1}$ and $4 \mathrm{~cm}^{-1}$ resolution.

\subsection{Adsorption Tests and Modeling}

The adsorption isotherms of methylene blue dye and phenol were obtained using $10 \mathrm{mg}$ of $\mathrm{AC}$ adsorbent and $10 \mathrm{~mL}$ of adsorbate at varying concentrations $\left(25,50,100,250,500\right.$ and $\left.1000 \mathrm{mg} \mathrm{L}^{-1}\right)$. AC-adsorbate mixtures were stirred at $100 \mathrm{rpm}$ for $24 \mathrm{~h}$ at room temperature $\left(25 \pm 2{ }^{\circ} \mathrm{C}\right)$. The equilibrium concentration was determined in a UV-visible spectrophotometer (AJX-3000PC, AJ Lab, AJ Micronal, Sao Paulo, Brazil) at of $665 \mathrm{~nm}$ and $270 \mathrm{~nm}$ for methylene blue and phenol, respectively. The Langmuir (Equation (2)) and Freundlich (Equation (3)) isotherm models [15] were used to analyze the data:

$$
\mathrm{q}_{\mathrm{eq}}=\left(\mathrm{q}_{\mathrm{m}} \mathrm{K}_{\mathrm{L}} \mathrm{C}_{\mathrm{eq}}\right) /\left(1+\mathrm{K}_{\mathrm{L}} \mathrm{C}_{\mathrm{eq}}\right)
$$

where $\mathrm{q}_{\mathrm{eq}}$ is the equilibrium concentration of $\mathrm{AC}\left(\mathrm{mg} \mathrm{g}^{-1}\right), \mathrm{C}_{\mathrm{e}}$ is the equilibrium concentration in the solution $\left(\mathrm{mg} \mathrm{L}^{-1}\right), \mathrm{q}_{\mathrm{m}}$ is the maximum capacity of adsorption of the $\mathrm{AC}\left(\mathrm{mg} \mathrm{g}^{-1}\right)$ and $\mathrm{K}_{\mathrm{L}}$ is the Langmuir adsorption constant $\left(\mathrm{L} \mathrm{mg}^{-1}\right)$.

$$
\mathrm{q}_{\mathrm{eq}}=\mathrm{K}_{\mathrm{F}} \mathrm{C}_{\mathrm{e}}^{(1 / \mathrm{n})}
$$

where $K_{F}$ is a constant that indicated the relative capacity of adsorption $\left(\mathrm{mg} \mathrm{g}^{-1}\right)\left(\mathrm{L} \mathrm{g}^{-1}\right)^{-(1 / n)}$ and $n$ is related to the intensity of adsorption of the AC.

\subsection{Iodine Number (IN) and Surface Area with Methylene Blue- $S_{M B}$}

The iodine number, defined as the absorption of iodine in $\mathrm{mg} \mathrm{g}^{-1} \mathrm{AC}$, was determined according to ASTM D4607-14 [16].

The surface area estimated with methylene blue $\left(\mathrm{S}_{\mathrm{MB}}\right)$ was obtained as reported in Equation (4) [17]:

$$
\mathrm{S}_{\mathrm{MB}}=\mathrm{S}_{\mathrm{MB}}{ }^{\circ} \mathrm{q}_{\mathrm{m}}
$$


where $\mathrm{S}_{\mathrm{MB}}{ }^{\circ}$ is the methylene blue surface area $\left(1.93 \mathrm{~m}^{2} \mathrm{mg}^{-1}\right)$ and $\mathrm{q}_{\mathrm{m}}$ is the maximum capacity of adsorption of the $\mathrm{AC}\left(\mathrm{mg} \mathrm{g}^{-1}\right)$.

\subsection{Estimation of the Brunauer, Emmett and Teller (BET) Surface Area}

The micropore volume, total pore volume and AC surface areas were estimated from the IN and maximum adsorption of methylene blue $\left(\mathrm{q}_{\mathrm{m}}\right)$. Structural Characterization of Activated Carbon (SCAC) software was used with the data to estimate the micropore volume, the total pore volume and the BET surface area of ACs [18].

\section{Results and Discussion}

\subsection{Chemical Composition of Fibers}

The chemical compositions of the untreated AP and BP used in AC preparation are described in Table 1. AP and BP have low ash and high lignin contents which are important characteristics in producing AC with optimal properties. High lignin contents provide high yields thereby contributing to the fixed carbon content at the end of carbonization and activation processes. Lignin biochar was shown to have a much higher yield than cellulose or pine wood [19] probably due to the higher decomposition temperature of lignin. Decomposition of hemicellulose, cellulose and lignin occur in the range of 200-260, 240-350 and $280-500{ }^{\circ} \mathrm{C}$, respectively [20]. Lignin decomposes at higher temperatures and over a much wider temperature range than do hemicellulose or cellulose; the aromatic rings of lignin make it much less susceptible to degradation and require high temperatures.

Table 1. Chemical composition of the of Leopoldinia piassaba (AP) and Attalea funifera Martius (BP).

\begin{tabular}{cccccc}
\hline \multirow{2}{*}{ Fiber Source } & \multicolumn{5}{c}{ Chemical Composition (\%) } \\
\cline { 2 - 6 } & Cellulose & Hemicellulose & Lignin & Extract & Ash \\
\hline AP & $19.30 \pm 0.08$ & $20.83 *$ & $55.86 \pm 0.36$ & $3.41 \pm 0.23$ & $0.59 \pm 0.02$ \\
BP & $27.51 \pm 0.08$ & $26.03 *$ & $45.93 \pm 1.49$ & $1.48 \pm 0.09$ & $0.76 \pm 0.08$ \\
\hline \multicolumn{7}{c}{ *Calculated by difference. }
\end{tabular}

AC derived from AP had higher lignin and extractives and lower cellulose, hemicelluloses and ash than AC derived from BP. The results found in this work, for the chemical composition of BP-Un, agree with those obtained by Schuchardt et al. [21], who found values of 0.8, 0.7, 45.0, 28.6 and 25.8 for ash, extractives, lignin (Klason), cellulose and hemicellulose, respectively.

\subsection{Elemental Composition}

Elemental composition of the piassava fibers, charcoal and activated carbon are shown in Table 2. AP had higher lignin (Table 1) and N (Table 2) contents that BP. However, after the pretreatments by Corona discharge or extraction, the two samples had similar values.

AP-Un-Ch had higher C than BP-Un-Ch. The comparative increase in $\mathrm{C}$ and the resulting decrease in $\mathrm{H}$ and $\mathrm{O}$ during thermal conversion are shown in Table 2. High heat treatment volatilizes $\mathrm{H}-$, $\mathrm{O}-$ and N-containing compounds [22] and results in high C contents. Pretreatments mostly affected the elemental composition of Ch (AP-Un-Ch, AP-Co-Ch, AP-Ex-Ch, BP-Un-Ch, BP-Co-Ch and BP-Ex-Ch).

In addition to the elements reported here, silica is also found in both AP and BP and was found to be $52 \%$ in A. funifera in the form of $\mathrm{SiO}_{2}$ [23] and occurred as bodies with protrusions of about $20 \mu \mathrm{m}$ in diameter taking up most of the space in a single cell $[24,25]$. Energy dispersive X-ray analysis showed that the bodies were mostly of silica [26]. 
Table 2. Elemental composition of piassava fibers (untreated and pretreated), charcoal and activated carbons.

\begin{tabular}{ccccc}
\hline Samples. & C (\%) & O (\%) & N (\%) & H (\%) \\
\hline AP-Un & 53.13 & 40.07 & 1.57 & 5.22 \\
AP-Co & 52.24 & 41.24 & 1.37 & 5.14 \\
AP-Ex & 52.77 & 40.66 & 1.34 & 5.22 \\
BP-Un & 50.61 & 42.85 & 1.15 & 5.39 \\
BP-Co & 52.28 & 41.18 & 1.05 & 5,49 \\
BP-Ex & 52.76 & 40.74 & 1.01 & 5.49 \\
AP-Un-Ch & 78.22 & 16.76 & 2.42 & 2.57 \\
AP-Co-Ch & 74.34 & 20.51 & 2.34 & 2.79 \\
AP-Ex-Ch & 73.37 & 21.24 & 2.79 & 2.57 \\
BP-Un-Ch & 69.44 & 26.69 & 1.38 & 2.47 \\
BP-Co-Ch & 79.50 & 16.27 & 1.47 & 2.75 \\
BP-Ex-Ch & 78.23 & 17.63 & 1.41 & 2.72 \\
AP-Un-AC & 82.03 & 13.53 & 2.52 & 1.82 \\
AP-Co-AC & 84.48 & 11.86 & 1.85 & 1.77 \\
AP-Ex-AC & 82.66 & 13.51 & 1.96 & 1.85 \\
BP-Un-AC & 83.38 & 13.66 & 1.39 & 1.52 \\
BP-Co-AC & 81.37 & 15.65 & 1.37 & 1.51 \\
BP-Ex-AC & 82.45 & 14.79 & 1.40 & 1.27 \\
\hline
\end{tabular}

C, Carbon; O, Oxygen; H, Hydrogen; N, Nitrogen; AP, Amazon piassava (Leopoldinia piassaba); BP, Bahia piassava (Attalea funifera Martius). Pretreatments: Un, untreated; Co, Corona electrical discharge; Ex, extraction; $\mathrm{Ch}$, charcoal; AC, activated carbon.

\subsection{Infrared Spectroscopy (FTIR)}

FTIR was used to identify specific functional groups in AP-Un and BP-Un and compare the results with the pretreated samples and with the charcoal and activated carbons obtained from the piassava fibers (Figure 1).

The FTIR spectra between 2000 and $500 \mathrm{~cm}^{-1}$ best describes functional groups in the samples. However, countless peaks in this region due the stretching and deformational vibrations of functional groups belonging to lignin and carbohydrates create overlapping peaks that make interpretation difficult. Close inspection reveals that AP-Un and BP-Un spectra (Figure 1a) have peaks at $1715 \mathrm{~cm}^{-1}$ characterizing $\mathrm{C}=\mathrm{O}$ (unconjugated ketone, conjugated carboxylic acids groups and ester groups of carbohydrates), $1600 \mathrm{~cm}^{-1}$ representative of $C=C$ (aromatic ring of lignin) plus $C=O, 1510 \mathrm{~cm}^{-1}$ attributed to lignin backbone, $1270 \mathrm{~cm}^{-1}$ as lignin guaiacyl ring plus $\mathrm{C}=\mathrm{O}$ and $1055 \mathrm{~cm}^{-1}$ assigned to $\mathrm{C}-\mathrm{O}(\mathrm{H})$ of carbohydrates [27-29].

In BP-Un and AP-Un (Figure 1a) the peaks at 1270 and $1055 \mathrm{~cm}^{-1}$ have about the same intensity, however, the lignin peaks, notably the peak at $1510 \mathrm{~cm}^{-1}$, are more intense in AP-Un (Figure 1a) than in BP-Un. The greater intensity of the lignin peaks confirms that AP-Un contains more lignin than BP-Un (Table 1).

According to Sadeghnejad et al. [30], corona treatment induces changes in material surface properties mostly due to reactions between covalent bonds in atmospheric oxygen and carbons on the sample surface. However, such change is not obvious in the spectra (Figure 1b) perhaps because corona treatment occurs on material surfaces, therefore, once the material has been ground for measurement by FTIR, the differences are no longer apparent in the resulting spectra.

A peak at $1560 \mathrm{~cm}^{-1}$, attributed to $\mathrm{C}=\mathrm{C}$ of the aromatic skeleton may be seen in charcoal spectra in both AP-Un-Ch and BP-Un-Ch (Figure 1d). The $1560 \mathrm{~cm}^{-1}$ may be due to an increase in carbonization that results in dehydrogenation and the formation of double bonds that indicated aromatization of the material $[27,28]$. Table 2 presents data that confirm the decrease in hydrogen in the charcoals.

The $1050 \mathrm{~cm}^{-1}$ peak disappears in the charcoal spectra (Figure $1 \mathrm{~d}-\mathrm{f}$ ) indicating carbohydrate degradation. A peak appears at about $1190 \mathrm{~cm}^{-1}$ showing that the aromatic structure of lignin has changed due to carbonization. (Yang et al. 2007). 
Neither pretreatment had a significant effect on charcoal or activated carbons (Figure 1d-i).
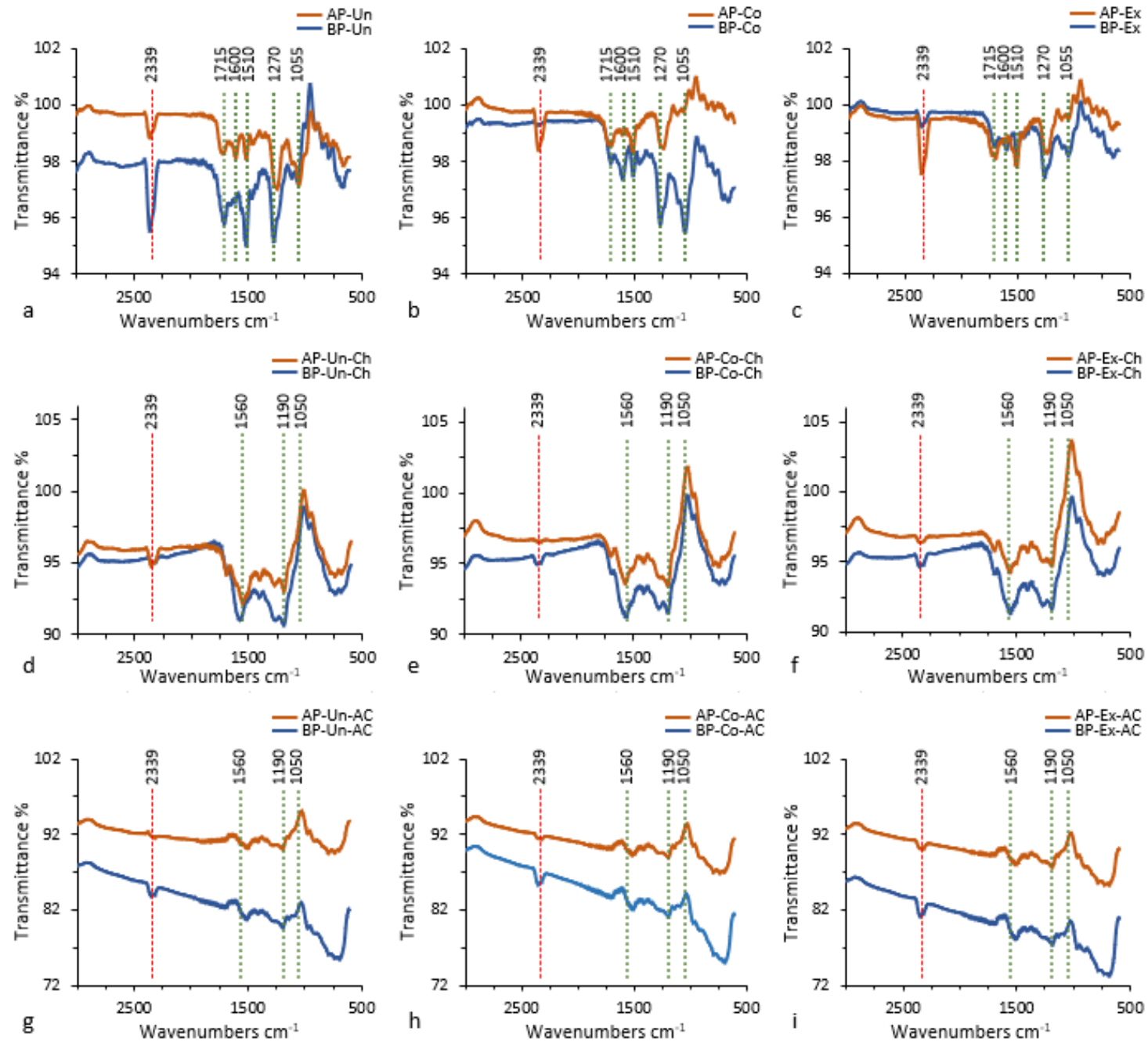

Figure 1. Typical infrared spectra of Leopoldinia piassaba and Attalea funifera Martius raw, milled fibers $(\mathbf{a}-\mathbf{c})$, charcoal precursor $(\mathbf{d}-\mathbf{f})$ and activated carbon $(\mathbf{g}-\mathbf{i})$. Fibers without pretreatment $(\mathbf{a}, \mathbf{d}, \mathbf{g})$, fibers pretreated by Corona electrical discharge $(\mathbf{b}, \mathbf{e}, \mathbf{h})$ and fibers pretreated by solvent extraction $(\mathbf{c}, \mathbf{f}, \mathbf{i})$. The vertical lines $(\mathbf{a}-\mathbf{c})$ correspond to specific functional groups: $1715 \mathrm{~cm}^{-1}(C=O), 1600 \mathrm{~cm}^{-1}(C=C$ of the aromatic ring of lignin plus $\mathrm{C}=\mathrm{O}$ ), $1510 \mathrm{~cm}^{-1}$ (lignin backbone), $1270 \mathrm{~cm}^{-1}$ (lignin guaiacyl ring plus $\mathrm{C}=\mathrm{O})$ and $1055 \mathrm{~cm}^{-1}(\mathrm{C}-\mathrm{O}(\mathrm{H})$ of carbohydrates). Note that $\mathrm{BP}-\mathrm{Un}$ and AP-Un (a) have the same intensity at peaks 1270 and $1055 \mathrm{~cm}^{-1}$. The peak at higher intensity at the peak $1510 \mathrm{~cm}^{-1}$ in AP-Un compared to BP-Un is indicative of higher lignin in AP-Un than in BP-Un. The peaks at $1560 \mathrm{~cm}^{-1}$, attributed to $\mathrm{C}=\mathrm{C}$ of the aromatic skeleton, indicates dehydrogenation, the formation of double bonds and aromatization of the material in AP-Un-Ch and BP-Un-Ch). The $1050 \mathrm{~cm}^{-1}$ peak has disappeared (d,e), suggesting carbohydrate degradation. The peak at $1190 \mathrm{~cm}^{-1}$ shows the change of aromatic structure of the lignin due to the carbonization. The pretreatments had no significant effect on either charcoal or activated carbons (d-i). AP, L. piassaba (Amazon piassava); the peaks at 2339 correspond to $\mathrm{CO}_{2}$ stretching (a-i). BP, A. funifera (Bahia piassava); Ch, charcoal; AC, activated carbon; Un, untreated (no pretreatment); Co, Corona electrical discharge pretreatment; Ex, solvent extraction pretreatment.

\subsection{Adsorption Tests}

Figures 2 and 3 show the isotherms that can be classified as type I (Langmuir type). According to the International Union of Pure and Applied Chemistry (IUPAC) classification, the Langmuir type of isotherm indicates high affinity between adsorbate and adsorbent. The adsorption isotherm is 
an important tool that reveals the specific relationship between the adsorbate molecules and the carbonaceous adsorbents [31]. The Langmuir and Freundlich parameters, for methylene blue and phenol (Table 3) show that the piassava ACs adsorbed higher quantities of methylene blue than phenol and that there was an influence from the pretreatments in the adsorption processes of the two compounds. The Langmuir model assumes a monolayer coverage of dyes over a homogenous adsorbent surface without further adsorption occurring in the occupied sites. In comparison, a heterogeneous adsorption was described by the Freundlich isotherm. The Freundlich model showed a continued increase in the concentration of dye on the adsorbent surface [32] and did not assume homogenous site energies or limited adsorption.AP-AC have higher adsorption capacity for methylene blue than BP-AC. AC produced from extracted AP and BP (AP-Ex-AC and BP-Ex-AC) had higher adsorption capacity than other pretreatments tested. The Langmuir model showed a better fit to the isotherm data than the Freundlich model as indicated by the $\mathrm{R}^{2}$ (Qe vs. Ce) values. The better fit Langmuir model indicated that adsorption occurred on a homogeneous surface [33].
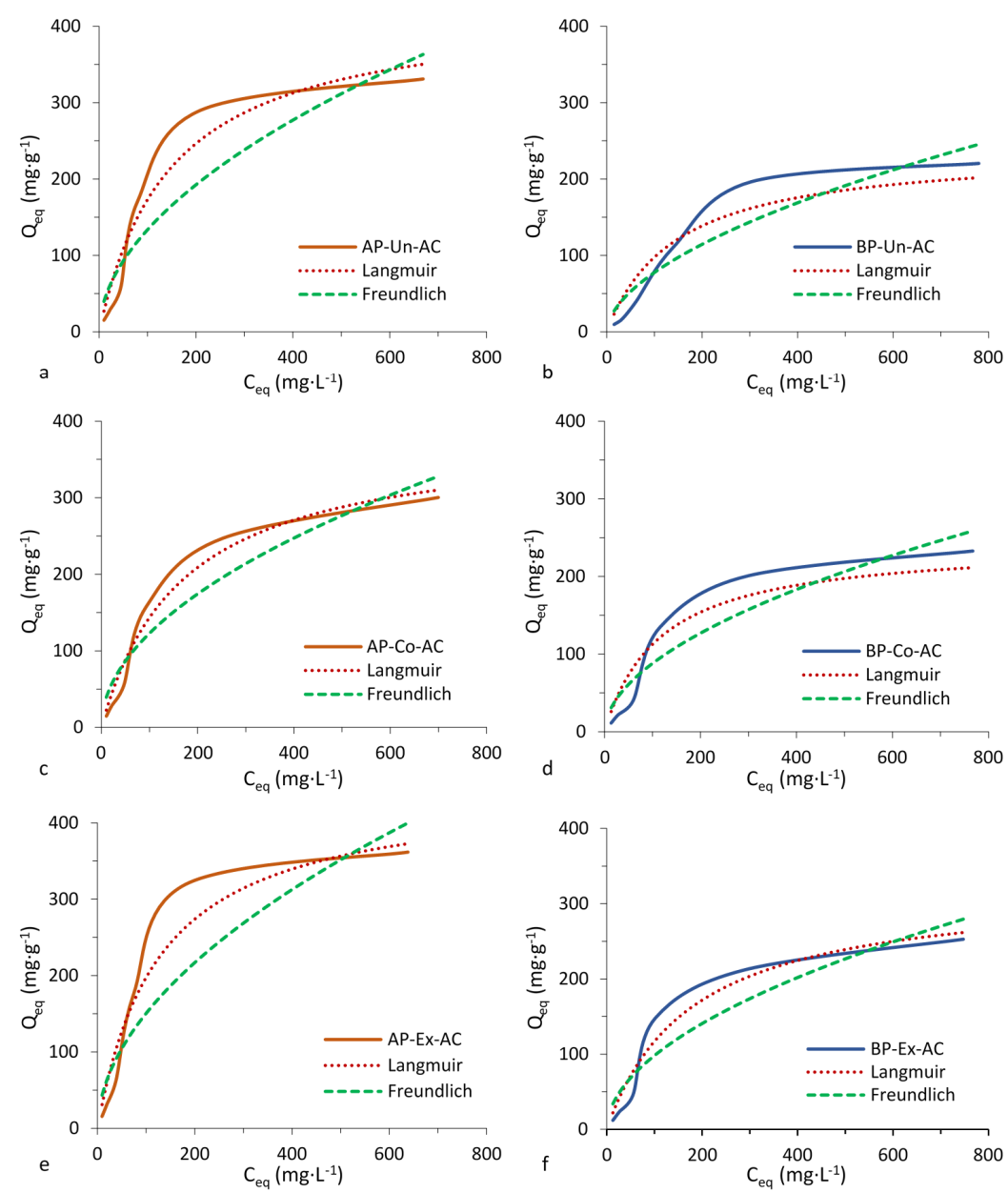

Figure 2. Methylene blue dye adsorption isotherms of piassava activated carbon with and without pretreatments comparing Langmuir and Freundlich curves. AP, Amazon piassava; BP, Bahia piassava; $\mathrm{Ch}$, charcoal; $\mathrm{AC}$, activated carbon; Un, untreated, no pretreatment; $\mathrm{Co}$, Corona electrical discharge pretreatment; Ex, solvent extraction pretreatment. 

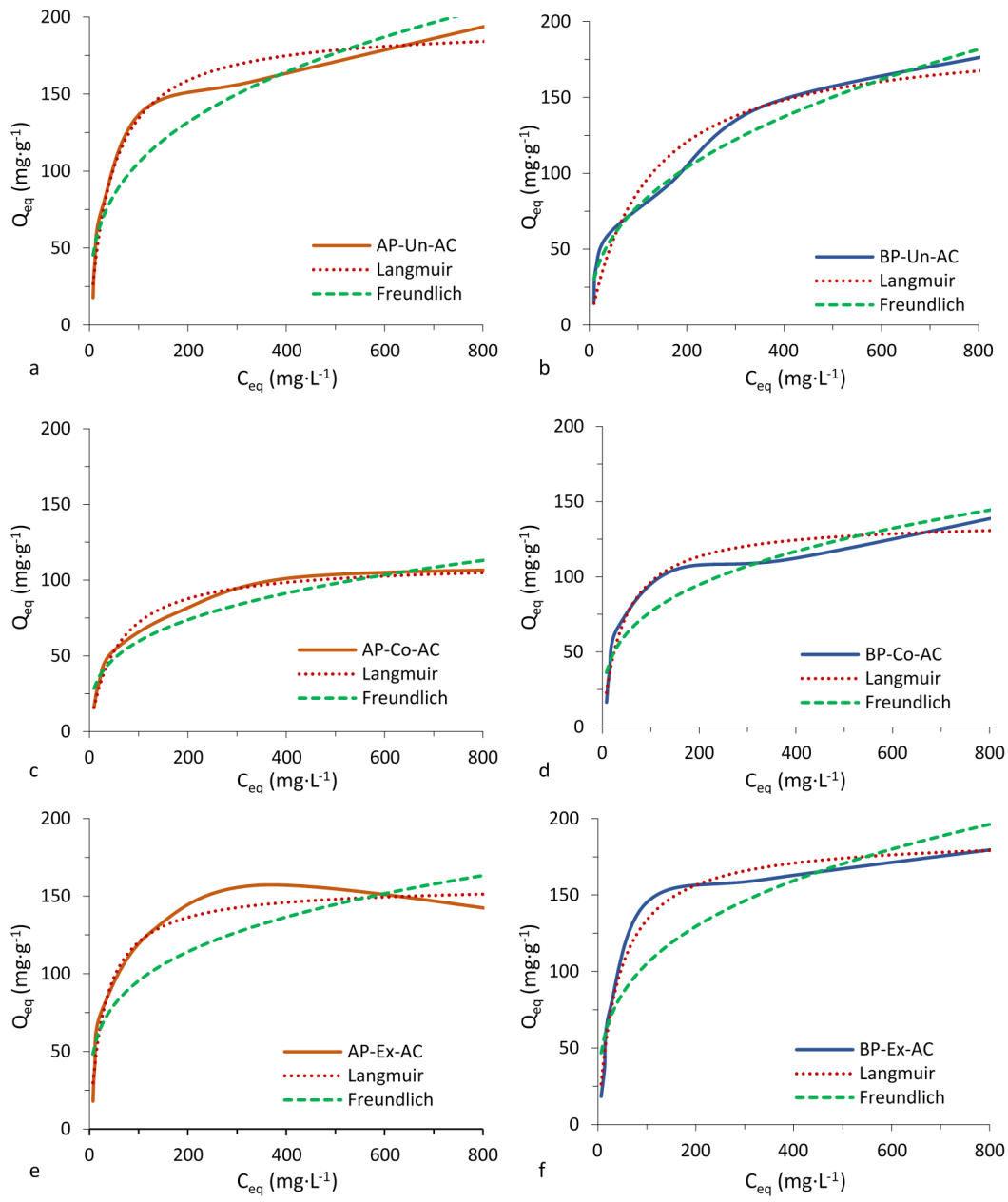

Figure 3. Phenol adsorption isotherms of piassava activated carbons with and without pretreatments comparing Langmuir and Freundlich curves. AP, Amazon piassava; BP, Bahia piassava; Ch, charcoal; AC, activated carbon; Un, untreated, no pretreatment; Co, Corona electrical discharge pretreatment; Ex, solvent extraction pretreatment.

Table 3. Langmuir and Freundlich parameters for the adsorption of methylene blue and phenol by the activated carbons obtained in this study.

\begin{tabular}{|c|c|c|c|c|c|c|c|}
\hline \multirow{2}{*}{ Compound } & \multirow{2}{*}{$\begin{array}{c}\text { Activated } \\
\text { Carbons (AC) }\end{array}$} & \multicolumn{3}{|c|}{ Langmuir Parameters } & \multicolumn{3}{|c|}{ Freundlich Parameters } \\
\hline & & $\mathrm{q}_{\mathrm{m}}$ & $\mathrm{K}_{\mathrm{L}}$ & $\mathbf{R}^{2}$ & $\mathbf{K}_{\mathrm{F}}$ & $1 / n$ & $\mathbf{R}^{2}$ \\
\hline \multirow{3}{*}{ Methylene blue } & AP-Un-AC & 427 & 0.007 & 0.96 & 12 & 0.526 & 0.87 \\
\hline & AP-Ex-AC & 446 & 0.008 & 0.96 & 13 & 0.527 & 0.86 \\
\hline & BP-Un-AC & 239 & 0.007 & 0.93 & 6 & 0.560 & 0.90 \\
\hline \multirow{4}{*}{ Phenol } & AP-Un-AC & 194 & 0.022 & 0.99 & 24 & 0.319 & 0.93 \\
\hline & AP-Co-AC & 112 & 0.018 & 0.99 & 14 & 0.307 & 0.95 \\
\hline & AP-Ex-AC & 156 & 0.033 & 0.98 & 29 & 0.258 & 0.83 \\
\hline & BP-Un-AC & 192 & 0.008 & 0.96 & 12 & 0.405 & 0.98 \\
\hline
\end{tabular}

$\mathrm{q}_{\mathrm{m}}=$ maximum quantity of adsorption $\left(\mathrm{mg} \mathrm{g}^{-1}\right) ; \mathrm{KL}=$ Langmuir constant $\left(\mathrm{L} \mathrm{mg}^{-1}\right) ; \mathrm{R}^{2}=$ correlation coefficient; $\mathrm{K}_{\mathrm{F}}=$ Freundlich constant $\left(\mathrm{mg} \mathrm{g}^{-1}\right)\left(\mathrm{L} \mathrm{g}^{-1}\right)^{-1 / \mathrm{n}} ; 1 / \mathrm{n}=$ Freundlich parameter. AP, Amazon piassava; BP, Bahia piassava; $\mathrm{Ch}$, charcoal; $\mathrm{AC}$, activated carbon; Un, untreated, no pretreatment; $\mathrm{Co}$, Corona electrical discharge pretreatment; Ex, solvent extraction pretreatment. 
The $\mathrm{R}^{2}$ (Qe vs. Ce) values for adsorption of phenol by AP-AC fit well to the Langmuir model. BP-Un-AC fit well to the Freundlich model whereas BP-Co-AC and BP-Ex-AC fit well to the Langmuir model. AP-Un-AC and BP-Un-AC had the highest adsorption capacity values for phenol compared to other ACs. ACs produced with Corona pretreated fibers (AP-Co-AC and BP-Co-AC) had decreased adsorption compared to other ACs. The adsorption capacity is also influenced by surface chemistry probably due to the presence of superficial functional groups and heteroatoms in the ACs. Chemical composition may be an additional factor affecting the surface chemistry of the ACs. Several factors may contribute to the adsorption capacity of phenol in addition to the best fit model that is provided to explain its adsorption. The effective adsorbent capacity is determined by the initial concentration of the adsorbent, ionic strength, temperature and $\mathrm{pH}$, all of which significantly affect phenol removal efficiency [34,35]. Xiong et al. [36] showed that phenol was removed more efficiently at an alkaline $\mathrm{pH}$ during the initial $25 \mathrm{~min}$ of reaction time and leveled off thereafter. Beker, et al. state that surface $\mathrm{pH}$ of adsorbents decreases with increasing degree of activation and that with increasing alkalinity, a reduction in adsorption capacity results. The optimal $\mathrm{pH}$ of 6.5 was found for adsorption of phenol. However, pH affects the type and ionic state of surface functional groups [37], so adsorbance capacity depends on the functional groups on the activated carbon. In this study, $\mathrm{pH}$ was not determined, however, FTIR results indicate a slightly acidic $\mathrm{pH}$ of $\mathrm{AC}$ due to the presence a strong peak at about $2339 \mathrm{~cm}^{-1}$ (Figure 1) indicative of stretching of $\mathrm{CO}_{2}$ [38].

Piassava AC in this study was shown to have greater capacity to adsorb methylene blue (223-424 $\mathrm{mg} \mathrm{g}^{-1}$ ) compared to other ACs found in literature [1,6,32,39-42]. AC adsorption for phenol in this study (125-226 $\mathrm{mg} \mathrm{g}^{-1}$ ) were similar to reported values in the literature (145-278 $\left.\mathrm{mg} \mathrm{g}^{-1}\right)$ [1,6,43,44].

Avelar et al. [1] showed that activated carbons produced from piassava fibers have high adsorption capacity for specific compounds, most often better than commercial AC used for comparison in the study of these authors.

Castro et al. [6] reported a $\mathrm{q}_{\mathrm{m}}$ of 388 for adsorption of methylene blue (Corona pretreatment), whereas, in the present work, a lower $\mathrm{q}_{\mathrm{m}}$ value of 385 is reported. The pretreatments for the two studies were slightly different which is perhaps the reason for the numerical differences in adsorption of methylene blue. In Castro et al. [6], the fibers were Corona pretreated whole whereas, in this study, the fibers were ground prior to Corona pretreatment. Perhaps in the previous work, the application of Corona pretreatment on whole fibers was more homogeneous than grinding the fibers prior to pretreatment.

\subsection{Surface Area of the ACs}

The iodine number, methylene blue adsorption and BET (Est-S $\mathrm{BET}_{\mathrm{BET}}$ ) surface area estimations of AC are shown in Table 4. The iodine number and the methylene blue number are important and can be used to estimate of the surface area, of the micropore volume and of the total pore volume of activated carbon samples through multiple regression, thus, the two parameters are important since the materials possess different pore sizes which can be accessed by the different molecules according to the pore geometry [18]. IN is the capacity of the adsorbent (AC) to decolorize a compound and indicates adsorbent microporosity [45] and degree of activation [39]. Methylene blue adsorption studies are widely used to evaluate adsorbents. Due the dimensions of the methylene blue molecule, the dye serves as a visible marker and an indicator of mesoporosity and, to a lesser extent, microporosity. The iodine molecule is relatively small and is, therefore, an indicator of microporosity [18]. The development of pore structure in the AC during activation followed three main steps: (1) opening of unreachable pores, (2) creation of new pores and (3) enlargement of existing pores [31].

Pretreatment of AP and BP resulted in changes to the surface areas and pore volumes. In general, the AC produced from extracted pretreatment (AP-Ex-AC, BP-Ex-AC) had the largest surface areas of all ACs. During the extraction process, soluble phenolic and carbohydrate components were removed, eliminating pore obstruction by those components during the carbonization and activation processes. 
Corona electrical discharge pretreatment also showed potential to alter and improve the qualities of the resulting pretreated ACs.

Table 4. Textural characterization parameters of the activated carbons from piassava with different pretreatments.

\begin{tabular}{|c|c|c|c|c|c|}
\hline $\begin{array}{l}\text { Activated } \\
\text { Carbon }\end{array}$ & $\begin{array}{c}\mathrm{S}_{\mathrm{AM}} \\
\left(\mathrm{mg}^{2} \mathrm{~g}^{-1}\right)\end{array}$ & $\begin{array}{c}\mathrm{IN} \\
\left(\mathrm{mg} \mathrm{g}^{-1}\right)\end{array}$ & $\begin{array}{c}\text { Est-S } \\
\left(\mathrm{mg}^{2} \mathrm{~g}^{-1}\right)\end{array}$ & $\begin{array}{c}V_{\text {total }} \\
\left(\mathrm{cm}^{3} \mathrm{~g}^{-1}\right)\end{array}$ & $\begin{array}{c}V_{\text {micro }} \\
\left(\mathrm{cm}^{3} \mathrm{~g}^{-1}\right)\end{array}$ \\
\hline AP-Un-AC & 824 & 508 & $611 \pm 67$ & $0.99 \pm 0.13$ & $0.98 \pm 0.16$ \\
\hline AP-Co-AC & 743 & 514 & $597 \pm 65$ & $0.91 \pm 0.12$ & $0.79 \pm 0.13$ \\
\hline AP-Ex-AC & 861 & 572 & $679 \pm 74$ & $0.98 \pm 0.13$ & $0.95 \pm 0.15$ \\
\hline BP-Un-AC & 461 & 525 & $539 \pm 59$ & $0.64 \pm 0.08$ & $0.31 \pm 0.05$ \\
\hline BP-Co-AC & 469 & 539 & $552 \pm 60$ & $0.65 \pm 0.08$ & $0.32 \pm 0.05$ \\
\hline BP-Ex-AC & 625 & 575 & $619 \pm 68$ & $0.81 \pm 0.10$ & $0.57 \pm 0.09$ \\
\hline
\end{tabular}

$\mathrm{S}_{\mathrm{MB}}=$ surface area estimated of methylene blue; IN = iodine number; Est-S $\mathrm{S}_{\mathrm{BET}}=$ estimated BET surface area; $\mathrm{V}_{\text {total }}=$ estimated total pore volume; $\mathrm{V}_{\text {micro }}=$ estimated micropore volume. AP, Amazon piassava; $\mathrm{BP}$, Bahia piassava; Ch, charcoal; $\mathrm{AC}$, activated carbon; Un, untreated, no pretreatment; $\mathrm{Co}$, Corona electrical discharge pretreatment; Ex, solvent extraction pretreatment.

The differences between AP-AC and BP-AC seems to be associated with the chemical composition of the untreated raw materials (Table 2) which influences the pore formation and surface areas of the resulting ACs. AP has higher lignin content than BP. Based on the findings of [46], one would expect a decrease in surface area with an increase in lignin content since their conclusion is that due to the large numbers of oxygen-containing functional groups in cellulose and hemicellulose, the small molecules $\left(\mathrm{H}_{2} \mathrm{O}, \mathrm{CO}_{2}\right.$ and $\left.\mathrm{CO}\right)$ would volatilize during heat treatment and be replaced by micropores. They state that since lignin has aromatic units that are chemically inert, a nonporous $\mathrm{AC}$ would be produced. However, Deng et al. [46] used chemical activation and treated at $400{ }^{\circ} \mathrm{C}$, at which temperature lignin would not decompose. In this study, activation was with $\mathrm{CO}_{2}$ at $800{ }^{\circ} \mathrm{C}$, above the temperature that lignin would start to decompose. Delignification of Elmwood was used to release sugars of hemicellulose for production of value-added products, a high-lignin fraction resulted from the process and was converted into an additional high-value microporous AC of high surface area $\left(1220 \mathrm{~m}^{2} \mathrm{~g}^{-1}\right)$ [47].

The estimated surface areas (Est-S $S_{\mathrm{BET}}$ ) of ACs in the present study were lower than those reported in the literature that used chemical activation [1,31-33,39]. Chemical activation typically yields AC with higher surfaces area than physical activation. Values of the same magnitude were found when compared with studies that performed physical activation [1,6,45]. Maneerung et al. [45] reported SBET values of $737 \mathrm{~m}^{2} \mathrm{~g}^{-1}$ from woody biomass after steam or $\mathrm{CO}_{2}$ activation at $800{ }^{\circ} \mathrm{C}$ with corresponding yields of $55 \%$ and $39 \%$, respectively. The starting material was residual charcoal from mesquite (Prosopis spp.) chips which had been processed for syngas. Thus, the feedstock precursor was very different in the Maneerung et al. [45] study than that in this study in that there was probably little or no volatile compounds remaining associated with the charcoal that could get redeposited on the carbon [6] effectively clogging or reducing the pore diameters or numbers. The conditions for activation were for $3 \mathrm{~h}$ at a gas flow rate of $90 \mathrm{~mL} \mathrm{~min}^{-1}$ in Maneerung et al. [45] vs. $2 \mathrm{~h}$ at a flow rate of $150 \mathrm{~mL} \mathrm{~min}-1$ in this study. Activation at elevated temperatures for long duration, generally results in a reduction in AC yield. According to Maneerung et al. [45], AC surface area increases with increasing process temperature and with the amount of activating agent.

In AP-AC and BP-AC, the chemical differences between the piassavas and the two pretreatments (Corona electrical discharge and extraction) influenced the final AC properties. However, the AP-AC and BP-AC had properties similar to those found in the literature. The ACs of this work were physically activated, which is an advantage, since there is no need for extra washing or the use of expensive reagents. 


\section{Conclusions}

ACs prepared from Amazon and Bahia piassava fibers, with and without pretreatment, by physical activation with $\mathrm{CO}_{2}$ have potential for use as adsorbent. The pretreatments applied to the fibers influenced the properties of the ACs.

The initial chemical compositions of Amazon and Bahia piassavas affect the physical-chemical characteristics of the resulting AC due to the higher lignin content in AP compared to BP. The ACs had higher adsorption capacity of methylene blue than phenol, according to adsorption isotherms and Langmuir and Freundlich parameters. Extraction as a pretreatment improved AC properties over Corona electrical discharge pretreatment. All of the ACs in this work had good adsorbent properties, employing extraction as a pretreatment was an improvement over values reported in the literature and AP-AC had better properties than BP-AC.

This study provides relevant information on the characteristics of the ACs produced from untreated and pretreated piassava fibers and verifies previously reported research.

Author Contributions: Conceptualization, J.P.C., G.H.D.T., and M.L.B.; data curation, J.P.C., A.N., P.F.T., D.F.W., and M.L.B.; formal analysis, J.P.C., D.F.W., and M.L.B.; funding acquisition, J.P.C., and M.L.B.; investigation, J.P.C., A.N., G.H.D.T., D.F.W., and M.L.B.; methodology, J.P.C., A.N., G.H.D.T., D.F.W., and M.L.B.; project administration, J.P.C., and M.L.B.; resources, J.P.C., J.R.C.N., A.N., P.F.T., G.H.D.T., D.F.W., and M.L.B.; supervision, J.P.C, P.F.T., G.H.D.T., and M.L.B.; validation, J.P.C., A.N., D.F.W., and M.L.B.; visualization J.P.C., J.R.C.N., A.N., P.F.T., G.H.D.T., D.F.W., and M.L.B.; writing—original draft, J.P.C., J.R.C.N., A.N., P.F.T., G.H.D.T., D.F.W., and M.L.B.; writing-review \& editing, J.P.C., J.R.C.N., A.N., P.F.T., G.H.D.T., D.F.W., and M.L.B. All authors have read and agreed to the published version of the manuscript.

Funding: This research was funded by Fundação Amparo à Pesquisa do Estado do Amazonas (RH-Doutorado005/2012), Conselho Nacional de Pesquisa e Desenvolvimento (CNPq_Process n. 201900/2014-9), Coordenação de Aperfeiçoamento de Pessoal de Nível Superior-Brasil (CAPES)-Finance Code 001.

Acknowledgments: The authors thank Tina Williams and Sean Flynn for formatting and proof-reading the manuscript.

Conflicts of Interest: The authors declare no conflict of interest. The funders had no role in the design of the study; in the collection, analyses, or interpretation of data; in the writing of the manuscript, or in the decision to publish the results.

Disclaimer: Mention of trade names or commercial products in this publication is solely for the purpose of providing specific information and does not imply recommendation or endorsement by the U.S. Department of Agriculture.

EEO Statement: The U.S. Department of Agriculture prohibits discrimination in all its programs and activities on the basis of race, color, national origin, age, disability, and where applicable, sex, marital status, familial status, parental status, religion, sexual orientation, genetic information, political beliefs, reprisal, or because all or part of an individual's income is derived from any public assistance program. (Not all prohibited bases apply to all programs.) Persons with disabilities who require alternative means for communication of program information (Braille, large print, audiotape, etc.) should contact USDA's TARGET Center at (202) 720-2600 (voice and TDD). To file a complaint of discrimination, write to USDA, Director, Office of Civil Rights, 1400 Independence Avenue, S.W., Washington, D.C. 20250-9410, or call (800) 795-3272 (voice) or (202) 720-6382 (TDD). USDA is an equal opportunity provider and employer.

\section{References}

1. Avelar, F.F.; Bianchi, M.L.; Goncalves, M.; da Mota, E.G. The use of piassava fibers (Attalea funifera) in the preparation of activated carbon. Bioresour. Technol. 2010, 101, 4639-4645. [CrossRef]

2. Dabioch, M.; Skorek, R.; Kita, A.; Janoska, P.; Pytlakowska, K.; Zerzucha, P.; Sitko, R. A study on adsorption of metals by activated carbon in a large-scale (municipal) process of surface water purification. Cent. Eur. J. Chem. 2013, 11, 742-753. [CrossRef]

3. Demirbas, E.; Kobya, M.; Sulak, M. Adsorption kinetics of a basic dye from aqueous solutions onto apricot stone activated carbon. Bioresour. Technol. 2008, 99, 5368-5373. [CrossRef] [PubMed]

4. Soleimani, M.; Kaghazchi, T. Adsorption of gold ions from industrial wastewater using activated carbon derived from hard shell of apricot stones-An agricultural waste. Bioresour. Technol. 2008, 99, 5374-5383. [CrossRef]

5. Nabais, J.M.V.; Laginhas, C.E.C.; Carrott, P.; Carrott, M.R. Production of activated carbons from almond shell. Fuel Process. Technol. 2011, 92, 234-240. [CrossRef] 
6. Castro, J.P.; Nobre, J.R.C.; Bianchi, M.L.; Trugilho, P.F.; Napoli, A.; Chiou, B.-S.; Williams, T.G.; Wood, D.F.; Avena-Bustillos, R.J.; Orts, W.J. Activated carbons prepared by physical activation from different pretreatments of amazon piassava fibers. J. Nat. Fibers 2019, 16, 961-976. [CrossRef]

7. Martins, A.F.; Cardoso, A.D.L.; Stahl, J.A.; Diniz, J. Low temperature conversion of rice husks, eucalyptus sawdust and peach stones for the production of carbon-like adsorbent. Bioresour. Technol. 2007, 98, 1095-1100. [CrossRef]

8. Associação Brasileira de Normas Técnicas (Brazilian National Standards Organization), Madeira: Determinação do Material Solúvel em Etanol-Tolueno e em Diclorometano e em Acetona: Método de Ensaio; Associação Brasileira de Normas Técnicas (Brazilian National Standards Organization): Rio de Janeiro, Brazil, 2010; p. 3.

9. Browning, B.L. The Chemistry of Wood. In The Chemistry of Wood; Interscience: New York, NY, USA, 1963; p. 574.

10. Kennedy, J.F.; Phillips, G.O.; Williams, P.A. Wood and Cellulosics: Industrial Utilisation, Biotechnology, Structure and Properties; Ellis Horwood Limited: Hemel Hempstead, UK, 1987.

11. Associação Brasileira de Normas Técnicas (Brazilian National Standards Organization), Pasta Celulósica e Madeira-Determinação de Lignina Insolúvel em Ácido: Método de Ensaio; Associação Brasileira de Normas Técnicas (Brazilian National Standards Organization): Rio de Janeiro, Brazil, 2010; p. 6.

12. Goldschmid, O. Ultraviolet spectra. In Lignins: Occurrence, Formation, Structure and Reactions; John Wiley \& Sons: New York, NY, USA, 1971; pp. 241-298.

13. Associação Brasileira de Normas Técnicas (Brazilian National Standards Organization), Papel, Cartão, Pastas Celulósicas e Madeira-Determinação do Resíduo (Cinza) Após a Incineração a $525^{\circ} \mathrm{C}$ : Método de Ensaio; Associação Brasileira de Normas Técnicas (Brazilian National Standards Organization): Rio de Janeiro, Brazil, 2003; p. 4.

14. Paula, L.E.d.R.; Trugilho, P.F.; Napoli, A.; Bianchi, M.L. Characterization of residues from plant biomass for use in energy generation. Cerne 2011, 17, 237-246. [CrossRef]

15. Kumar, K.V.; Sivanesan, S. Equilibrium data, isotherm parameters and process design for partial and complete isotherm of methylene blue onto activated carbon. J. Hazard. Mater. 2006, 134, 237-244. [CrossRef]

16. ASTM International. Standard Test Method for Determination of Iodine Number of Activated Carbon; ASTM D4607-14; American Society for Testing and Materials: West Conshohocken, PA, USA, 2014.

17. Stavropoulos, G.; Zabaniotou, A. Production and characterization of activated carbons from olive-seed waste residue. Microporous Mesoporous Mater. 2005, 82, 79-85. [CrossRef]

18. Nunes, C.A.; Guerreiro, M.C. Estimation of surface area and pore volume of activated carbons by methylene blue and iodine numbers. Química Nova 2011, 34, 472-476. [CrossRef]

19. Li, J.; Li, Y.; Wu, Y.; Zheng, M. A comparison of biochars from lignin, cellulose and wood as the sorbent to an aromatic pollutant. J. Hazard. Mater. 2014, 280, 450-457. [CrossRef] [PubMed]

20. Browne, F.L. Theories of the Combustion of Wood and Its Control: A Survey of the Literature; Forest Products Laboratory, Forest Service, USA Department of Agriculture: Madison, WI, USA, 1958.

21. Schuchardt, U.; Bianchi, M.; Gonçalves, A.; Curvelo, A.; Biscolla, F.; Peres, L. Piassava fibers (Attalea funifera). 1. Chemical analysis, extraction and reactivity of its lignin. Cellul. Chem. Technol. 1995, 29, 705-712.

22. Sekirifa, M.L.; Hadj-Mahammed, M.; Pallier, S.; Baameur, L.; Richard, D.; Al-Dujaili, A.H. Preparation and characterization of an activated carbon from a date stones variety by physical activation with carbon dioxide. J. Anal. Appl. Pyrolysis 2013, 99, 155-160. [CrossRef]

23. Nogueira, B.R.; Chinellato, A.; Ortiz, A.V.; Parveen, A.; Rangari, V.K.; Moura, E.A. Thermal and morphological behavior of EVOH/piassava fiber composites. In Characterization of Minerals, Metals, and Materials; The Minerals, Metals, \& Materials Society: Warrendale, PA, USA, 2012; pp. 373-380.

24. d'Almeida, J.R.M.; Aquino, R.C.M.P.; Monteiro, S.N. Dynamic Mechanical Behavior of Piassava Fibers (Attalea funifera) Reinforced Polyester Composites. Int. J. Polym. Mater. 2007, 56, 397-403. [CrossRef]

25. Nascimento, D.C.O.; Ferreira, A.S.; Monteiro, S.N.; Aquino, R.C.M.; Kestur, S.G. Studies on the characterization of piassava fibers and their epoxy composites. Compos. Part A 2012, 43, 353-362. [CrossRef]

26. Elzubair, A.; Bonelli, C.M.C.; Suarez, J.C.M.; Mano, E.B. Morphological, Structural, Thermal and Mechanical Characterization of Piassava Fibers. J. Nat. Fibers 2007, 4, 13-31. [CrossRef]

27. Bui, N.Q.; Fongarland, P.; Rataboul, F.; Dartiguelongue, C.; Charon, N.; Vallée, C.; Essayem, N. FTIR as a simple tool to quantify unconverted lignin from chars in biomass liquefaction process: Application to SC ethanol liquefaction of pine wood. Fuel Process. Technol. 2015, 134, 378-386. [CrossRef] 
28. Nishimiya, K.; Hata, T.; Imamura, Y.; Ishihara, S. Analysis of chemical structure of wood charcoal by X-ray photoelectron spectroscopy. J. Wood Sci. 1998, 44, 56-61. [CrossRef]

29. Saka, S. Chemical composition and distribution. In Wood and Cellulosic Chemistry; Marcel Dekker Ltd.: New York, NY, USA, 2000; pp. 51-82.

30. Sadeghnejad, A.; Aroujalian, A.; Raisi, A.; Fazel, S. Antibacterial nano silver coating on the surface of polyethylene films using corona discharge. Surf. Coat. Technol. 2014, 245, 1-8. [CrossRef]

31. Omri, A.; Benzina, M. Activated carbons prepared from Thymelaea hirsuta wood: Sustainable adsorbents for polyvinyl alcohol. Environ. Prog. Sustain. Energy 2016, 35, 70-79. [CrossRef]

32. Mahamad, M.N.; Zaini, M.A.A.; Zakaria, Z.A. Preparation and characterization of activated carbon from pineapple waste biomass for dye removal. Int. Biodeterior. Biodegrad. 2015, 102, 274-280. [CrossRef]

33. Gao, J.-J.; Qin, Y.-B.; Zhou, T.; Cao, D.-D.; Xu, P.; Hochstetter, D.; Wang, Y.-F. Adsorption of methylene blue onto activated carbon produced from tea (Camellia sinensis L.) seed shells: Kinetics, equilibrium, and thermodynamics studies. J. Zhejiang Univ. Sci. B 2013, 14, 650-658. [CrossRef]

34. Abussaud, B.; Asmaly, H.A.; Saleh, T.A.; Gupta, V.K.; Atieh, M.A. Sorption of phenol from waters on activated carbon impregnated with iron oxide, aluminum oxide and titanium oxide. J. Mol. Liq. 2016, 213, 351-359. [CrossRef]

35. Feng, J.; Qiao, K.; Pei, L.; Lv, J.; Xie, S. Using activated carbon prepared from Typha orientalis Presl to remove phenol from aqueous solutions. Ecol. Eng. 2015, 84, 209-217. [CrossRef]

36. Xiong, W.; Cui, W.; Li, R.; Feng, C.; Liu, Y.; Ma, N.; Deng, J.; Xing, L.; Gao, Y.; Chen, N. Mineralization of phenol by ozone combined with activated carbon: Performance and mechanism under different $\mathrm{pH}$ levels. Environ. Sci. Ecotechnol. 2020, 1, e100005. [CrossRef]

37. Beker, U.; Ganbold, B.; Dertli, H.; Gülbayir, D.D. Adsorption of phenol by activated carbon: Influence of activation methods and solution pH. Energy Convers. Manag. 2010, 51, 235-240. [CrossRef]

38. LibreTexts. Infrared Spectroscopy Absorption Table. Available online: https://chem.libretexts.org/ Bookshelves/Ancillary_Materials/Reference/Reference_Tables/Spectroscopic_Parameters/Infrared_ Spectroscopy_Absorption_Table (accessed on 25 June 2020).

39. Köseoğlu, E.; Akmil-Başar, C. Preparation, structural evaluation and adsorptive properties of activated carbon from agricultural waste biomass. Adv. Powder Technol. 2015, 26, 811-818. [CrossRef]

40. Kumar, P.S.; Ramalingam, S.; Sathishkumar, K. Removal of methylene blue dye from aqueous solution by activated carbon prepared from cashew nut shell as a new low-cost adsorbent. Korean J. Chem. Eng. 2011, 28, 149-155. [CrossRef]

41. Nasuha, N.; Hameed, B. Adsorption of methylene blue from aqueous solution onto NaOH-modified rejected tea. Chem. Eng. J. 2011, 166, 783-786. [CrossRef]

42. Pezoti Jr, O.; Cazetta, A.L.; Souza, I.P.; Bedin, K.C.; Martins, A.C.; Silva, T.L.; Almeida, V.C. Adsorption studies of methylene blue onto $\mathrm{ZnCl}_{2}$-activated carbon produced from buriti shells (Mauritia flexuosa $\mathrm{L}$.). J. Ind. Eng. Chem. 2014, 20, 4401-4407. [CrossRef]

43. Miao, Q.; Tang, Y.; Xu, J.; Liu, X.; Xiao, L.; Chen, Q. Activated carbon prepared from soybean straw for phenol adsorption. J. Taiwan Inst. Chem. Eng. 2013, 44, 458-465. [CrossRef]

44. Zhang, D.; Huo, P.; Liu, W. Behavior of phenol adsorption on thermal modified activated carbon. Chin. J. Chem. Eng. 2016, 24, 446-452. [CrossRef]

45. Maneerung, T.; Liew, J.; Dai, Y.; Kawi, S.; Chong, C.; Wang, C.-H. Activated carbon derived from carbon residue from biomass gasification and its application for dye adsorption: kinetics, isotherms and thermodynamic studies. Bioresour. Technol. 2016, 200, 350-359. [CrossRef] [PubMed]

46. Deng, J.; Xiong, T.; Wang, H.; Zheng, A.; Wang, Y. Effects of Cellulose, Hemicellulose, and Lignin on the Structure and Morphology of Porous Carbons. ACS Sustain. Chem. Eng. 2016, 4, 3750-3756. [CrossRef]

47. Martín-Sampedro, R.; Eugenio, M.E.; Fillat, Ú.; Martín, J.A.; Aranda, P.; Ruiz-Hitzky, E.; Ibarra, D.; Wicklein, B. Biorefinery of Lignocellulosic Biomass from an Elm Clone: Production of Fermentable Sugars and Lignin-Derived Biochar for Energy and Environmental Applications. Energy Technol. 2019, 7, 277-287. [CrossRef]

(C) 2020 by the authors. Licensee MDPI, Basel, Switzerland. This article is an open access article distributed under the terms and conditions of the Creative Commons Attribution (CC BY) license (http://creativecommons.org/licenses/by/4.0/). 